\title{
Cytotoxic Sesquiterpene Lactones and other Constituents of Centaurea omphalotricha
}

\author{
El Hadj Kolli, ${ }^{a}$ Francisco León, ${ }^{* b}$ Fadila Benayache, ${ }^{c}$ Sara Estévez, ${ }^{d}$ José Quintana, ${ }^{d}$ \\ Francisco Estévez, ${ }^{d}$ Ignacio Brouard, ${ }^{b}$ Jaime Bermejo $^{b}$ and Samir Benayache ${ }^{*, a}$
}

${ }^{a}$ Laboratoire de Valorisation des Ressources Naturelles et Synthèse de Substances Bioactives, Equipe Associée à l'A.N.D.R.S. and 'Laboratoire de Phytochimie et Analyses Physico-Chimiques et Biologiques, Université Mentouri, Route de Ä̈n El Bey, 25000 Constantine, Algeria

${ }^{b}$ Instituto de Productos Naturales y Agrobiología, CSIC, Av. Astrofísico Fco. Sánchez, 3, 38206 La Laguna, Tenerife, Spain

${ }^{d}$ Departamento de Bioquímica, Unidad Asociada al CSIC, Facultad de Ciencias de la Salud, Universidad de Las Palmas de Gran Canaria, and Instituto Canario de Investigación del Cáncer, Av. S. Cristóbal, 35016 Las Palmas de Gran Canaria, Gran Canaria, Spain

\begin{abstract}
A investigação fitoquímica das partes aéreas de Centaurea omphalotricha levou ao isolamento de três lactonas sesquiterpênicas novas, 4'-acetilcinaropicrina, 4'-acetilcebelina F e 15-acetil desidromelitensina, juntamente com doze compostos conhecidos, sendo sete lactonas sesquiterpênicas, dois isoprenóides e três flavonóides. As estruturas dos novos compostos foram elucidadas por meio de RMN $1 \mathrm{D}$ e 2D, e espectrometria de massas, e por comparação com os dados descritos na literatura. $\mathrm{O}$ efeito de lactonas sesquiterpênicas sobre a viabilidade das células tumorais humanas, linhagens HL-60 e U937, também foi investigado e 3-acetilcinaropicrina e 4'-acetilcinaropicrina foram os compostos mais citotóxicos contra células de leucemia humana com valores de $\mathrm{IC}_{50}$ de 2,0 $\pm 0,9$ e 5,1 $\pm 0,4 \mu \mathrm{mol} \mathrm{L}{ }^{-1}$, respectivamente.
\end{abstract}

Phytochemical research of the aerial parts of Centaurea omphalotricha led to the isolation of three new sesquiterpene lactones, 4'-acetyl cynaropicrin, 4'-acetyl cebellin F and 15-acetyl dehydromelitensin, together with twelve known compounds, seven sesquiterpene lactones, two isoprenoids and three flavonoids. The structures of the new compounds were elucidated by means of extensive 1D and 2D NMR, and MS, and by comparison with reported data in the literature. The effect of sesquiterpene lactones on the viability of the human tumor cell lines HL-60 and U937 was also investigated and 3-acetyl cynaropicrin, and 4'-acetyl cynaropicrin were found to be the most cytotoxic compounds against human leukemia cells with an $\mathrm{IC}_{50}$ values of $2.0 \pm 0.9$ and $5.1 \pm 0.4 \mu \mathrm{mol} \mathrm{L}{ }^{-1}$, respectively.

Keywords: Centaurea, Asteraceae, sesquiterpene lactones, cytotoxic activity, HL-60

\section{Introduction}

The genus Centaurea (Asteraceae: Centaureinae) comprises more than 500 species, most of which grow around the Mediterranean and in Western Asia. ${ }^{1}$ Centaurea species have long been used for their biological properties, mainly as anti-inflammatory, ${ }^{2}$ antipyretic, ${ }^{3}$ cytotoxic, ${ }^{4}$ antibacterial, ${ }^{5}$ and antiproliferative agents. ${ }^{6}$ Phytochemical investigations revealed that the compounds responsible for their pharmacological properties are flavonoids ${ }^{7}$ and sesquiterpene lactones predominantly germacranolides,

*e-mail: jfleon@ipna.csic.es, sbenayache@yahoo.com eudesmanolides, elemanolides, and guaianolides. ${ }^{8}$ As a part of our continuing search for novel, plant-derived anticancer chemotherapeutic agents and our systematic investigation of the composition of plants of this genus, ${ }^{4,9}$ we have investigated the chemical constituents of the aerial parts of Centaurea omphalotricha Coss. \& Durieu ex Batt. et Trab., a species endemic to Algeria and Tunisia. ${ }^{10,11}$

The present work describes the isolation and structural elucidation of the constituents of the ethanolic-aqueous extract of the aerial parts of $C$. omphalotricha. The constituents of this extract were purified by column chromatography and preparative TLC. Thus, fifteen compounds were isolated including 4'-acetyl cynaropicrin (1), 4'-acetyl cebellin F (2) 
<smiles>[R9]CC(=C)C(=O)O[C@H]1CC(=C)[C@H]2C[C@@H](O[R9])C(=S)[C@H]2[C@H]2OC(=O)C(=C)[C@H]12</smiles>

$1 \mathrm{R}=\mathrm{Ac} ; \mathrm{R}_{1}=\mathrm{H}$

$5 \mathrm{R}=\mathrm{H} ; \mathrm{R}_{1}=\mathrm{Ac}$

$8 \mathrm{R}=\mathrm{R}_{1}=\mathrm{H}$<smiles>C=C1C(=O)O[C@@H]2C(=C)C(=O)O[C@@H]12</smiles>

4<smiles></smiles>

2<smiles>C=C[C@]1(C)C[C@@H](OC(=O)C(=C)CO)[C@H](C(=C)CO)[C@@H]2OC(=O)C(=C)[C@H]21</smiles>

6<smiles>C=C1C(=O)O[C@H]2[C@@H]1[C@H](O)C[C@]1(C)C=CC=C(COC(C)=O)[C@H]21</smiles>

3<smiles>C=C[C@]1(C)C[C@H](O)[C@H]2[C@@H](C)C(=O)O[C@H]2[C@]1(C)COC(C)=O</smiles>

7<smiles></smiles>

9<smiles>C=C1C[C@H](O)[C@H]2[C@@H](C)C(=O)O[C@@H]2C1CC(=C)[C@H](C)O</smiles>

10

Figure 1. Structures of compounds 1-10.

and 15-acetyl dehydromelitensin (3), which are new in the literature, together with the seven sesquiterpene lactones: linichlorin B (4), ${ }^{12} 3$-acetyl cynaropicrin (5), ${ }^{13}$ 8-(4-hydroxymethacrylate)-dehydromelitensin $(6),{ }^{14}$ 15-acetyl melitensin (7), ${ }^{15}$ cynaropicrin $(\mathbf{8}),{ }^{16}$ desacylcynaropicrin $(9)^{16}$ and 8-hydroxy-11,13-dihydrozaluzanin C (10): ${ }^{16}$ two isoprenoids: 3-hydroxy-5,6-epoxy-ionone, ${ }^{17}$ dehydrovomifoliol ${ }^{17}$ and three flavonoids: circimaritin, apigenin and luteolin. ${ }^{18}$ The structures of the known compounds were confirmed by comparison of their spectroscopic data (MS, ${ }^{1} \mathrm{H}$ and ${ }^{13} \mathrm{C}$ NMR) with literature references. In this study we also demonstrate that the isolated sesquiterpene lactones 1-6 (Figure 1) induce cytotoxicity in human leukemia cell lines HL-60 and U937.

\section{Experimental}

\section{General}

Optical rotations were measured using a Perkin-Elmer model 343 polarimeter using $\mathrm{CHCl}_{3}$ as solvent. UV spectra were recorded using a SHIMADZU model UV-1700 spectrophotometer. IR spectra were recorded as $\mathrm{CHCl}_{3}$ films on $\mathrm{NaCl}$ plates, using a Bruker model IFS-55 and Perkin-Elmer model FTIR-8400S spectrophotometer.
${ }^{1} \mathrm{H}$ and ${ }^{13} \mathrm{C}$ NMR spectra were obtained on a Bruker model Avance 400 and AMX-500 spectrometer with standard pulse sequences, operating at 400 and $500 \mathrm{MHz}$ for ${ }^{1} \mathrm{H}$ and 100 and $125 \mathrm{MHz}$ for ${ }^{13} \mathrm{C}$, respectively. $\mathrm{CDCl}_{3}$ was used as solvent and TMS as internal standard. EIMS were taken on a Micromass model Autospec $(70 \mathrm{eV})$ spectrometer. HRESIMS was performed with a LCT Premier XE Micromass Waters spectrometer in positive ionization mode (Waters Corporation). Column chromatography (CC) was carried out with Si gel Fluka (cat. 60737) $(40-63 \mu \mathrm{m})$, and column fractions were monitored by TLC (Si gel $60 \mathrm{~F}_{254}$, $0.2 \mathrm{~mm}$, Macherey Nagel (cat. 818-333)) by detection with a spraying reagent $\left(\mathrm{CH}_{3} \mathrm{COOH} / \mathrm{H}_{2} \mathrm{O} / \mathrm{H}_{2} \mathrm{SO}_{4} ; 80: 16: 4\right)$ followed by heating at $100{ }^{\circ} \mathrm{C}$. Preparative TLC was carried out on $\mathrm{Si}$ gel $60 \mathrm{PF}_{254+366}(20 \times 20 \mathrm{~cm}, 1 \mathrm{~mm}$ thickness, Analtech (cat. 02014)).

\section{Plant material}

Aerial parts of Centaurea omphalotricha (Coss. \& Durieu ex Batt.) Willk. were collected from the Daya of Mogheul near Bechar in southwest Algeria (32.0192 N and $2.22 \mathrm{~W}$ ) in April 2010 and identified by Professor M. Kabeche of University of Setif and M. Benabdelhakem from the National Agency of Preservation of Natural 
Resources of Bechar. A voucher specimen (COB N. 175-2010) has been deposited in the Herbarium of Constantine University.

\section{Extraction and isolation}

Air-dried aerial parts (2604 g) of C. omphalotricha (Asteraceae) were powdered and macerated at room temperature with $\mathrm{EtOH} / \mathrm{H}_{2} \mathrm{O}(80: 20 \mathrm{v} / \mathrm{v})$ for $48 \mathrm{~h}$, three times. After filtration, the filtrate was concentrated and suspended in $\mathrm{H}_{2} \mathrm{O}(800 \mathrm{~mL})$. The residue was extracted successively with $\mathrm{CHCl}_{3}$, EtOAc and $n$-butanol. The organic phases were dried with $\mathrm{Na}_{2} \mathrm{SO}_{4}$, filtered using common filter paper and concentrated in vacuum at $25^{\circ} \mathrm{C}$ to obtain the following extracts: $\mathrm{CHCl}_{3}(10.0 \mathrm{~g})$, EtOAc $(9.8 \mathrm{~g})$ and $n$-butanol (41.8 g). The $\mathrm{CHCl}_{3}$ extract was fractionated by column chromatography (CC) ( $\mathrm{Si}$ gel; petroleum ether/EtOAc with increasing polarity; $100 \times 7 \mathrm{~cm})$ to yield 25 fractions (1-25). Fraction 22 (petroleum ether/ EtOAc, 65:35 and 45:55; $1.3 \mathrm{~g}$ ) was subjected to Si gel CC $\left(\mathrm{CH}_{2} \mathrm{Cl}_{2} / \mathrm{MeOH} ; 100 \times 1.5 \mathrm{~cm}\right)$ with increasing polarity to give 8 subfractions. Subfraction $1\left(\mathrm{CH}_{2} \mathrm{Cl}_{2} ; 220 \mathrm{mg}\right)$ was purified by preparative TLC ( $n$-hexane/ $\mathrm{Et}_{2} \mathrm{O}, 2: 4$, three elutions) to give dehydrovomifoliol (2.2 mg); subfraction $4\left(\mathrm{CH}_{2} \mathrm{Cl}_{2} / \mathrm{MeOH}, 96: 4 ; 413.6 \mathrm{mg}\right)$ was rechromatographed on a $\mathrm{Si}$ gel column $\left(\mathrm{CH}_{2} \mathrm{Cl}_{2} /\right.$ acetone; $\left.50 \times 1.5 \mathrm{~cm}\right)$ with increasing polarity to give 22 subfractions (sub1-sub 22). Sub $6\left(\mathrm{CH}_{2} \mathrm{Cl}_{2}\right.$ /acetone, 98:2; $\left.8.2 \mathrm{mg}\right)$ was purified by preparative TLC $\left(\mathrm{CH}_{2} \mathrm{Cl}_{2} /\right.$ EtOAc/acetone; 50:10:4) to afford compound 7 (4.2 mg); sub $9\left(\mathrm{CH}_{2} \mathrm{Cl}_{2}\right.$ /acetone, $96: 4$; $14.5 \mathrm{mg})$ was submitted to preparative TLC $\left(\mathrm{Et}_{2} \mathrm{O} / n\right.$-hexane, $4: 1$, three elutions) to give the new compound $3(1.8 \mathrm{mg})$ and 5 (1.3 mg); sub $10\left(\mathrm{CH}_{2} \mathrm{Cl}_{2} /\right.$ acetone, 96:4; $\left.16.9 \mathrm{mg}\right)$ gave after purification by preparative TLC ( $n$-hexane/ $\mathrm{Et}_{2} \mathrm{O}, 1: 5$, four elutions) 3-hydroxy-5,6-epoxy-ionone (3.8 mg); sub14 ( $\mathrm{CH}_{2} \mathrm{Cl}_{2}$ /acetone, 90:10; $16.3 \mathrm{mg}$ ) was rechromatographed by preparative TLC ( $n$-hexane/Et ${ }_{2} \mathrm{O}$, 1:5, four elutions) to afford compound 4 (3 mg).

Fraction 23 (petroleum ether/EtOAc, 40:60; $720 \mathrm{mg}$ ) which was purified by $\mathrm{Si}$ gel TLC on preparative plates $\left(\mathrm{CH}_{2} \mathrm{Cl}_{2} / \mathrm{MeOH} / \mathrm{AcOH} ; 80: 9: 1\right.$, one elution) gave in order of increasing polarity compound $\mathbf{9}(15.1 \mathrm{mg})$ and a mixture which was purified by TLC $\left(\mathrm{CH}_{2} \mathrm{Cl}_{2} / \mathrm{MeOH} / \mathrm{H}_{2} \mathrm{O}\right.$, 10:1:0.1, one elution) yielding compound $8(2.1 \mathrm{mg})$. Fraction 24 (petroleum ether/EtOAc 20:80; $1270 \mathrm{mg}$ ) was chromatographed on a $\mathrm{Si}$ gel $\mathrm{CC}\left(\mathrm{CH}_{2} \mathrm{Cl}_{2} /\right.$ isopropanol; $100 \times 1.5 \mathrm{~cm})$ with increasing polarity to give 26 subfractions. Subfraction $8\left(\mathrm{CH}_{2} \mathrm{Cl}_{2}\right.$ /isopropanol, 96:4; $113.3 \mathrm{mg}$ ) was submitted to preparative TLC ( $n$-hexane/ $\mathrm{Et}_{2} \mathrm{O}, 1: 2$ five elutions) to afford the new product $\mathbf{1}$ $(1.3 \mathrm{mg})$ and a mixture of compounds which was purified by preparative TLC $\left(\mathrm{CH}_{2} \mathrm{Cl}_{2} / \mathrm{MeOH}, 92: 8\right.$, two elutions) to yield the new product 2 (4 mg) and circimaritin $(3.4 \mathrm{mg})$. Subfraction $9\left(\mathrm{CH}_{2} \mathrm{Cl}_{2}\right.$ /isopropanol, $\left.96: 4 ; 87.7 \mathrm{mg}\right)$ was submitted to preparative TLC ( $n$-hexane/ $\mathrm{Et}_{2} \mathrm{O}, 1: 2$, three elutions) to yield 6 (4.6 mg). Subfraction $14\left(\mathrm{CH}_{2} \mathrm{Cl}_{2} /\right.$ isopropanol, 96:4; $14 \mathrm{mg}$ ) was a pure compound $\mathbf{1 0}$.

A part of the EtOAc extract (5.8 g) was chromatographed on a $\mathrm{Si}$ gel $\mathrm{CC}\left(\mathrm{CHCl}_{3} /\right.$ acetone, $\left.100 \times 7 \mathrm{~cm}\right)$ with increasing polarity to give 8 fractions. Fraction $8\left(\mathrm{CHCl}_{3} /\right.$ acetone, 50:50 to $100 \%$ acetone; $421.2 \mathrm{mg}$ ) was rechromatographed on a $\mathrm{Si}$ gel $\mathrm{CC}\left(\mathrm{CH}_{2} \mathrm{Cl}_{2} /\right.$ EtOAc; $\left.120 \times 1.5 \mathrm{~cm}\right)$ with increasing polarity to give 13 subfractions. Subfraction $5\left(\mathrm{CH}_{2} \mathrm{Cl}_{2} / \mathrm{EtOAc}, 80: 20 ; 11 \mathrm{mg}\right)$ afforded pure apigenin (10.2 mg). Subfraction $7\left(\mathrm{CH}_{2} \mathrm{Cl}_{2} / \mathrm{EtOAc}, 75: 25 ; 21.8 \mathrm{mg}\right)$ was rechromatographed by TLC using $\mathrm{CH}_{2} \mathrm{Cl}_{2} / \mathrm{MeOH} / \mathrm{H}_{2} \mathrm{O}$ (100:10:0.1) as mobile phase to yield luteolin (11.3 mg).

\section{4'-Acetyl cynaropicrin (1)}

Amorphous solid; $[\alpha]_{\mathrm{D}}^{25}=+94\left(\mathrm{c} 0.026, \mathrm{CHCl}_{3}\right)$; IR $(\mathrm{NaCl}) v_{\max } / \mathrm{cm}^{-1}: 3478,2939,1755,1740,1729,1642$, 1450, 1373, 1267, 1152, 1048, 1031, 961; ${ }^{1} \mathrm{H}$ NMR $\left(500 \mathrm{MHz}_{\mathrm{CDCl}}\right.$ ) see Table $1 ;{ }^{13} \mathrm{C} \mathrm{NMR}(125 \mathrm{MHz}$, $\mathrm{CDCl}_{3}$ ) see Table 2; HRESIMS positive ion $\mathrm{m} / \mathrm{z} 411.1428$ $[\mathrm{M}+\mathrm{Na}]^{+}\left(\right.$Calc. for $\left.\mathrm{C}_{21} \mathrm{H}_{24} \mathrm{O}_{7} \mathrm{Na}, 411.1420\right)$.

\section{4'-Acetyl cebellin F (2)}

Amorphous solid; $[\alpha]_{\mathrm{D}}^{25}=+81\left(\mathrm{c} 0.018, \mathrm{CHCl}_{3}\right)$; IR $(\mathrm{NaCl}) v_{\max } / \mathrm{cm}^{-1}: 3481,2937,1751,1729,1653,1374$, 1231, 1135, 1030, 910; ${ }^{1} \mathrm{H}$ NMR (500 MHz, $\mathrm{CDCl}_{3}$ ) see Table $1 ;{ }^{13} \mathrm{C}$ NMR $\left(\mathrm{CDCl}_{3}, 125 \mathrm{MHz}\right)$ see Table 2; HRESIMS positive ion $\mathrm{m} / z 425.1578[\mathrm{M}+\mathrm{Na}]^{+}$(Calc. for $\mathrm{C}_{22} \mathrm{H}_{26} \mathrm{O}_{7} \mathrm{Na}$, 425.1576).

\section{5-Acetyl dehydromelitensin (3)}

Amorphous solid; $[\alpha]_{\mathrm{D}}^{25}=+60\left(\mathrm{c} 0.009, \mathrm{CHCl}_{3}\right)$; IR $(\mathrm{NaCl}) v_{\max } / \mathrm{cm}^{-1}: 3420,2935,1751,1734,1727,1651$, 1384, 1239, 1137, 1051, 910; ${ }^{1} \mathrm{H}$ NMR (500 MHz, $\mathrm{CDCl}_{3}$ ) see Table 1; ${ }^{13} \mathrm{C}$ NMR (125 $\mathrm{MHz}, \mathrm{CDCl}_{3}$ ) see Table 2; HRESIMS positive ion $m / z$ 329.1360 [M + Na ${ }^{+}$, (Calc. for $\mathrm{C}_{17} \mathrm{H}_{22} \mathrm{O}_{5} \mathrm{Na}, 329.1365$ ).

\section{Cell culture and cytotoxicity assays}

The human leukemia HL-60 and U937 cells (DSMZ, German Collection of Microorganisms and Cell Cultures, Braunschweig, Germany) were grown in RPMI 1640 containing $2 \mathrm{mmol} \mathrm{L}^{-1} \mathrm{~L}$-glutamine supplemented with $10 \%(\mathrm{v} / \mathrm{v})$ heat-inactivated fetal bovine serum as previously described. ${ }^{19}$

Stock solutions of $25 \mathrm{mmol} \mathrm{L}^{-1}$ sesquiterpene lactones were made in dimethyl sulfoxide (DMSO) and further 
dilutions were made in culture media just before use. In all experiments, the final concentration of DMSO did not exceed $0.4 \%(\mathrm{v} / \mathrm{v})$, a concentration which is non toxic to the cells. The cytotoxicity of sesquiterpene lactones on human tumor cells was analyzed by colorimetric 3-[4,5-dimethylthiazol2-yl-]2,5-diphenyl tetrazolium bromide (MTT) assay as previously described. ${ }^{20}$ Concentrations inducing a $50 \%$ inhibition of cell growth $\left(\mathrm{IC}_{50}\right)$ were determined graphically using the curve fitting algorithm of the computer software Prism 4.0 (GraphPad). Values are means \pm SE from at least three independent experiments, each performed in triplicate. The antitumor agent etoposide was used as a positive control in both HL-60 $\left(\mathrm{IC}_{50}=0.4 \pm 0.1 \mu \mathrm{mol} \mathrm{L}{ }^{-1}\right)$ and $\mathrm{U} 937$ cells $\left(\mathrm{IC}_{50}=1.4 \pm 0.3 \mu \mathrm{mol} \mathrm{L}^{-1}\right)$.

\section{Results and Discussion}

Compound 1 was obtained as an amorphous solid. HRESIMS experiments indicated the molecular formula $\mathrm{C}_{21} \mathrm{H}_{24} \mathrm{O}_{7}$ (calc. for $[\mathrm{M}+\mathrm{Na}]^{+} 411.1420$; found 411.1428). The IR spectra exhibited absorption bands for $\mathrm{OH}$ groups $\left(3478 \mathrm{~cm}^{-1}\right)$ and for carbonyl groups $(1755(\alpha, \beta$-unsaturated$\gamma$-lactone), 1740 and 1729 (ester carbonyls) $\mathrm{cm}^{-1}$ ). The presence of these groups was confirmed by the ${ }^{1} \mathrm{H}$ (Table 1) and ${ }^{13} \mathrm{C}$ NMR spectra (Table 2). The ${ }^{1} \mathrm{H}$ NMR of $\mathbf{1}$ showed the presence of eight olefinic methylene protons at $\delta_{\mathrm{H}} 5.65$ (d, 1H, J3.1 Hz, H-13a), 6.27 (d, 1H, J3.5 Hz , H-13b), 4.98 (s, 1H, H-14a), 5.19 (s, 1H, H-14b), 5.41 (t, 1H, J $1.5 \mathrm{~Hz}$, H-15a), 5.53 (t, 1H, J 1.5 Hz, H-15b), 6.00 (s, 1H, H-3'a) and $6.49\left(\mathrm{~s}, 1 \mathrm{H}, \mathrm{H}-3\right.$ 'b), one acetyl group at $\delta_{\mathrm{H}} 2.14(\mathrm{~s}, 3 \mathrm{H}$, OAc), three oxygenated methines at $\delta_{\mathrm{H}} 4.29(\mathrm{dd}, 1 \mathrm{H}, J 10.5$, $9.0 \mathrm{~Hz}, \mathrm{H}-6), 4.60$ (tt, $1 \mathrm{H}, J$ 7.0, $1.5 \mathrm{~Hz}, \mathrm{H}-3$ ) and 5.19 (m, $1 \mathrm{H}, \mathrm{H}-8)$ and one oxygenated methylene at $\delta_{\mathrm{H}} 4.88(\mathrm{~s}, 2 \mathrm{H}$, $\left.\mathrm{H}_{2}-4^{\prime}\right)$. The connectivities were established by analysis of its COSY spectrum. The ${ }^{13} \mathrm{C}$ NMR (Table 2) and DEPT data indicated the presence of one carbonyl group corresponding to a $\gamma$-lactone, two ester carbonyl groups, three aliphatic methylene, eight olefinic, one methyl (acetate), and six methine carbons. Both the ${ }^{1} \mathrm{H}$ and ${ }^{13} \mathrm{C}$ NMR spectral data of compound $\mathbf{1}$ were close to those of cynaropicrin, ${ }^{16}$ with the exception of an extra acetyl group in compound $\mathbf{1}$, which was assigned by a HMBC experiment. Thus, the correlation observed between the signal at $\delta_{\mathrm{H}} 4.88\left(\mathrm{~s}, 2 \mathrm{H}, \mathrm{H}_{2}-4\right.$ ') and $\delta_{\mathrm{C}} 170.3$ (OAc), allowed us to confirm the position of the acetoxy group at the $\mathrm{C}-4$ ' position. Therefore, the structure of $\mathbf{1}$ was elucidated as 4'-acetyl cynaropicrin.

Compound 2 was obtained as an amorphous solid. The ${ }^{1} \mathrm{H}$ NMR data (Table 1) of $\mathbf{2}$ were very similar to those

Table 1. ${ }^{1} \mathrm{H}$ NMR data of compounds $\mathbf{1 - 3}$ in $\mathrm{CDCl}_{3}(\delta$ in ppm and $J$ in $\mathrm{Hz})$

\begin{tabular}{|c|c|c|c|}
\hline \multirow{2}{*}{ Proton } & 1 & 2 & 3 \\
\hline & $\delta_{\mathrm{H}}$ & $\delta_{\mathrm{H}}$ & $\delta_{\mathrm{H}}$ \\
\hline 1 & $3.02(d d d, 10.5,9.0,7.5)$ & $3.03(d d d, 11.0,10.5,7.5)$ & $5.82(d d, 17.4,10.7)$ \\
\hline $\begin{array}{l}2 \mathrm{a} \\
2 \mathrm{~b}\end{array}$ & $\begin{array}{c}1.75(d d d, 14.5,10.5,7.0) \\
2.22-2.27(\mathrm{~m})\end{array}$ & $\begin{array}{c}1.77(d d d, 13.0,10.5,7.5) \\
2.28(d t, 13.0,7.5)\end{array}$ & $\begin{array}{l}5.05(d, 10.7) \\
5.11(d, 17.4)\end{array}$ \\
\hline $\begin{array}{l}3 \mathrm{a} \\
3 \mathrm{~b}\end{array}$ & $4.60(t t, 7.0,1.5)$ & $4.61(t t, 7.5,1.5)$ & $\begin{array}{l}5.05(s) \\
5.45(s)\end{array}$ \\
\hline 5 & $2.89(t t, 9.0,1.5)$ & $2.89(t t, 11.0,1.5)$ & $2.46(d, 11.4)$ \\
\hline 6 & $4.29(d d, 10.5,9.0)$ & $4.28(d d, 11.0,9.0)$ & $4.16(t, 11.4)$ \\
\hline 7 & $3.20-3.25(m)$ & $3.21-3.26(m)$ & $2.67(t t, 11.4,3.0)$ \\
\hline 8 & 5.19 ( $m$, overlapped $)$ & $5.16(d d d, 9.3,5.1,4.0)$ & $4.15(t d, 11.4,4.1)$ \\
\hline $\begin{array}{l}9 a \\
9 b\end{array}$ & $\begin{array}{l}2.44(d d, 14.5,3.5) \\
2.75(d d, 14.5,5.0)\end{array}$ & $\begin{array}{l}2.41(d d, 14.6,4.0) \\
2.74(d d, 14.6,5.1)\end{array}$ & $\begin{array}{c}1.70(d d, 13.1,11.4) \\
1.91(d d, 13.1,4.1)\end{array}$ \\
\hline $\begin{array}{l}13 \mathrm{a} \\
13 \mathrm{~b}\end{array}$ & $\begin{array}{l}5.65(d, 3.1) \\
6.27(d, 3.5)\end{array}$ & $\begin{array}{l}5.62(d, 3.1) \\
6.27(d, 3.5)\end{array}$ & $\begin{array}{l}6.03(d, 3.0) \\
6.22(d, 3.0)\end{array}$ \\
\hline $\begin{array}{l}14 \mathrm{a} \\
14 \mathrm{~b}\end{array}$ & $\begin{array}{l}4.98(s) \\
5.19(s)\end{array}$ & $\begin{array}{l}4.98(s) \\
5.19(s)\end{array}$ & $1.14(s)$ \\
\hline $\begin{array}{l}15 \mathrm{a} \\
15 \mathrm{~b}\end{array}$ & $\begin{array}{l}5.41(t, 1.5) \\
5.53(t, 1.5)\end{array}$ & $\begin{array}{l}5.41(t, 1.5) \\
5.55(t, 1.5)\end{array}$ & $\begin{array}{l}4.52(d, 13.6) \\
4.57(d, 13.6)\end{array}$ \\
\hline $\begin{array}{l}3 ' \mathrm{a} \\
3{ }^{\prime} \mathrm{b}\end{array}$ & $\begin{array}{l}6.00(s) \\
6.49(s)\end{array}$ & $6.85(t q, 6.1,1.2)$ & - \\
\hline 4 ' & $4.88(s)$ & $4.83(d, 6.1)$ & - \\
\hline 5 & - & $1.98(d, 1.2)$ & - \\
\hline OAc & $2.14(s)$ & $2.15(s)$ & $2.13(s)$ \\
\hline
\end{tabular}


of $\mathbf{1}$, suggesting that both compounds are closely related in structure. The major variation is that compound $\mathbf{2}$ has a different acyl group. A detailed comparison of the ${ }^{1} \mathrm{H}$ (Table 1) and ${ }^{13} \mathrm{C}$ NMR (Table 2) signals of $\mathbf{2}$ and $\mathbf{1}$ revealed an extra carbon signal in ${ }^{13} \mathrm{C} \mathrm{NMR}$, besides the presence of a methyl group at $\delta_{\mathrm{H}} 1.98\left(\mathrm{~d}, 3 \mathrm{H}, J 1.2 \mathrm{~Hz}, \mathrm{H}_{3}-5^{\prime}\right)$ and a vinylic proton signal at $\delta_{\mathrm{H}} 6.85(\mathrm{tq}, 1 \mathrm{H}, J 6.1,1.2 \mathrm{~Hz}, \mathrm{H}-3$ ') in ${ }^{1} \mathrm{H}$ NMR suggesting that the substituent group in $\mathbf{2}$ is the 4-acetoxy-2-methyl butenoyl. The relative stereochemistry of the double bond in the acyl group was determined as $E$ based on the observed correlation between the signals at $\delta_{\mathrm{H}} 4.83$ and 1.98 in the ROESY spectrum. The combination of all the above data and the HRESIMS experiment led us to assign the structure of $\mathbf{2}$ as 4'-acetyl cebellin F.

Table 2. ${ }^{13} \mathrm{C}$ NMR data of compounds $\mathbf{1 - 3}$ in $\mathrm{CDCl}_{3}(\delta$ in ppm)

\begin{tabular}{|c|c|c|c|}
\hline \multirow{2}{*}{ Position } & 1 & 2 & 3 \\
\hline & $\delta_{\mathrm{C}}$ & $\delta_{\mathrm{C}}$ & $\delta_{\mathrm{C}}$ \\
\hline 1 & 45.4 & 45.4 & 146.0 \\
\hline 2 & 39.1 & 39.1 & 113.0 \\
\hline 3 & 73.8 & 73.9 & 116.9 \\
\hline 4 & 152.3 & 152.3 & 138.7 \\
\hline 5 & 51.4 & 51.4 & 51.5 \\
\hline 6 & 78.4 & 78.6 & 78.3 \\
\hline 7 & 46.7 & 47.9 & 55.1 \\
\hline 8 & 74.6 & 74.5 & 67.5 \\
\hline 9 & 37.1 & 37.3 & 49.8 \\
\hline 10 & 141.7 & 141.8 & 42.0 \\
\hline 11 & 137.4 & 137.4 & 137.4 \\
\hline 12 & 168.9 & 169.0 & 169.7 \\
\hline 13 & 122.5 & 122.1 & 120.5 \\
\hline 14 & 118.2 & 118.1 & 19.0 \\
\hline 15 & 113.6 & 113.6 & 67.2 \\
\hline $1^{\prime}$ & 164.3 & 166.1 & \\
\hline 2 & 135.2 & 130.2 & \\
\hline 3' & 129.1 & 136.4 & \\
\hline $4^{\prime}$ & 62.3 & 61.0 & \\
\hline 5, & & 12.9 & \\
\hline $\mathrm{OAc}$ & 20.8170 .3 & 20.8170 .7 & 21.0170 .6 \\
\hline
\end{tabular}

The HREIMS and ${ }^{13} \mathrm{C}$ NMR data of $\mathbf{3}$ indicated the molecular formula $\mathrm{C}_{17} \mathrm{H}_{22} \mathrm{O}_{5}$. The IR spectrum of this compound showed the presence of hydroxyl groups $\left(3420 \mathrm{~cm}^{-1}\right)$, and carbonyl groups $\left(1751,1734,1727 \mathrm{~cm}^{-1}\right)$. The ${ }^{1} \mathrm{H}$ NMR (Table 1) spectrum of $\mathbf{3}$ exhibited the presence of one methyl group at $\delta_{\mathrm{H}} 1.14\left(\mathrm{~s}, 3 \mathrm{H}, \mathrm{CH}_{3}-14\right)$, one acetyl methyl group at $2.13(\mathrm{~s}, 3 \mathrm{H}, \mathrm{OAc})$, one vinylic proton at $5.82(\mathrm{dd}, 1 \mathrm{H}, J 17.4,10.7 \mathrm{~Hz}, \mathrm{H}-1)$, and six olefinic methylene protons at $5.05(\mathrm{~d}, 1 \mathrm{H}, J 10.7 \mathrm{~Hz}, \mathrm{H}-2 \mathrm{a}), 5.11$ (d, 1H, J $17.4 \mathrm{~Hz}, \mathrm{H}-2 \mathrm{~b}$ ), 5.05 (s, 1H, H-3a), 5.45 (s, 1H, H-3b), 6.03 (d, 1H, J 3.0 Hz, H-13a), 6.22 (d, 1H, $J 3.0 \mathrm{~Hz}, \mathrm{H}-13 \mathrm{~b}$ ), typical of a 1,3,11(13)-elematrien-6,12olide. ${ }^{21,22}$ The relationships between the proton signals in 3 were established from the ${ }^{1} \mathrm{H}-{ }^{1} \mathrm{H}$ COSY spectrum, which disclosed the following connectivities: $\mathrm{H}-1$ with $\mathrm{H}_{2}-2$, $\mathrm{H}-5$ with $\mathrm{H}-6, \mathrm{H}-13$ with $\mathrm{H}-7, \mathrm{H}-8$ with $\mathrm{H}_{2}-9$. The ${ }^{13} \mathrm{C}$ NMR (Table 2) and DEPT spectral data indicated the presence of two carbonyl groups, corresponding to a $\gamma$-lactone, and an acetoxy group, six olefinic carbons, two methyl groups, two aliphatic methylene carbons, one of them oxygenated, four methine carbons, two of them oxygenated and one quaternary carbon. These assignments were similar to those of the known elemanolide dehydromelitensin. ${ }^{22}$ However, a hydroxyl group was replaced by an acetoxy group, the location of this group in $\mathbf{3}$ being confirmed by the low shift position $(+0.5 \mathrm{ppm})$ of the protons $\mathrm{H}_{2}-15$ at $\delta_{\mathrm{H}} 4.52(\mathrm{~d}$, $1 \mathrm{H}, J 13.6 \mathrm{~Hz}, \mathrm{H}-15 \mathrm{a})$ and 4.57 (d, 1H, J $13.6 \mathrm{~Hz}, \mathrm{H}-15 \mathrm{~b})$ in comparison with the ${ }^{1} \mathrm{H}$ NMR dehydromelitensin data, ${ }^{22}$ characteristic of the presence of an acetyl group in a primary hydroxyl. The structure of compound $\mathbf{3}$ was assigned and confirmed using HMBC, HSQC and ROESY data as 15-acetyl dehydromelitensin.

Sesquiterpene lactones have attracted much attention during the last three decades, because they display a wide range of biological activities, including antitumor and antiinflammatory properties. ${ }^{8,23}$ The structural requirement for the biological activities of these compounds is associated with $\alpha$-methylene- $\gamma$-butyrolactone moiety, which acts as alkylating agent in a Michael-type reaction with nucleophiles. ${ }^{24}$ Thus, sesquiterpene lactones are believed to exert their numerous biological activities through inhibition of enzymes and other functional proteins by forming covalent bonds with free cysteine residues in these macromolecules or by conjugation with glutathione..$^{25,26}$

Previous studies have shown that sesquiterpene lactones display cytotoxic properties in tumor cells ${ }^{8}$ and that the sesquiterpene lactone of the guaianolide type cynaropicrin induces cytotoxicity in U937 and Jurkat T cell lines. ${ }^{27} \mathrm{~A}$ quantitative structure-activity relationships (QSAR) study including four different skeletons of sesquiterpene lactones revealed the most active among the guaianolides and pseudoguainolides, and steric properties and electronic features as the most important descriptors. ${ }^{23}$ However, antiproliferative studies of the naturally occurring sesquiterpene lactones described in this paper in human leukemia cells have not yet been assessed.

Sesquiterpene lactones 1-6 were found to inhibit the growth and cell viability of HL-60 and U937 cells in culture as determined by the 3-[4,5-dimethylthiazol-2-yl]2,5- 
diphenyl tetrazolium bromide (MTT) dye-reduction assay (Table 3). In contrast, the sesquiterpene lactone $\mathbf{7}$ is not an effective antiproliferative agent showing an $\mathrm{IC}_{50}$ value higher than $100 \mu \mathrm{mol} \mathrm{L}^{-1}$ in leukemia cells, in accordance with the absence of the alkylating group, the exocyclic conjugated double bond.

Table 3. Effects of compounds 1-7 on the growth of the human leukemia cell lines

\begin{tabular}{lcc}
\hline \multirow{2}{*}{ Compound } & \multicolumn{2}{c}{$\mathrm{IC}_{50} /\left(\mu \mathrm{mol} \mathrm{L}^{-1}\right)$} \\
\cline { 2 - 3 } $\mathbf{1}$ & $\mathrm{HL}-60$ & $\mathrm{U} 937$ \\
$\mathbf{2}$ & $7.1 \pm 0.4$ & $10.8 \pm 4.1$ \\
$\mathbf{3}$ & $25.8 \pm 1.9$ & $10.4 \pm 1.9$ \\
$\mathbf{4}$ & $5.4 \pm 1.3$ & $29.9 \pm 4.4$ \\
$\mathbf{5}$ & $2.0 \pm 0.9$ & $6.8 \pm 2.2$ \\
$\mathbf{6}$ & $5.6 \pm 2.1$ & $3.1 \pm 0.6$ \\
$\mathbf{7}$ & $>100$ & $11.7 \pm 1.5$ \\
\hline
\end{tabular}

Cells were cultured for $72 \mathrm{~h}$ and the $\mathrm{IC}_{50}$ values were calculated as described in the Experimental section. The data shown represent the means \pm SEM of 3-5 independent experiments with three determinations in each.

Among the different sesquiterpene lactones, the presence of the exocyclic, conjugated double bond is essential for the cytotoxic activity against HL-60 and U937 cells. Compounds 1, 2, 4, 5 and $\mathbf{6}$ displayed similar potency in both cell lines. The potency of these sesquiterpene lactones might be explained by their lipophilicity. However, other factors, such as molecular geometry and the chemical environment of the target sulfhydryl may also influence the activity of sesquiterpene lactones. All these guaianolides contain an ester functional group at C-8. The sesquiterpene lactone 8-(4-hydroxymethacrylate)-dehydromelitensin 6 also contains an ester near from the exocyclic methylene bond. The presence of this group appears to be important, since compound $\mathbf{3}$ (15-acetyl dehydromelintensin) - which does not contain this functional group - was less cytotoxic than $\mathbf{6}$.

In conclusion, the Algerian plant Centaurea omphalotricha has been chemically studied for the first time, and three new sesquiterpene lactones have been identified along with twelve known compounds. The naturally occurring sesquiterpene lactones evaluated in the present study were strongly cytotoxic against human leukemia cell lines and the results of the present study may lead to the discovery of new and highly specific antitumor agents against leukemia cells.

\section{Supplementary Information}

Spectra of compounds 1-3 are available free of charge at http://jbcs.sbq.org.br as PDF file.

\section{Acknowledgments}

This work was supported in part by grants from the NATO Public Diplomacy Division (Science for Peace and Security Section) CBP.MD.CLG 983840, the Spanish Ministry of Science and Innovation and from the European Regional Development Fund (SAF2010-21380) and MAEC-Agencia Española de Cooperación y Desarrollo PCI (A1/035449/11). F. L. was supported by the JAE-DOC Program from the Spanish Ministry of Science and Innovation and the CSIC. S. E. thanks the Spanish Ministry of Education for a collaboration studentship. Thanks are also due to the Algerian Ministry of Higher Education and Scientific Research for financial support.

\section{References}

1. Susanna, A.; Garcia-Jacas, N. In Systematics, Evolution and Biogeography of Compositae; Funk, V. A.; Susanna, A.; Stuessy, T. F.; Bayer, R. J, eds.; International Association for Plant Taxonomy: Vienna, Austria, 2009, pp. 293-313.

2. Koca, U.; Suntar, I. P.; Keles, H.; Yesilada, E.; Akkol, E. K.; J. Ethnopharmacol. 2009, 126, 551.

3. Akkol, E. K.; Arif, R.; Ergun, F.; Yesilada, E.; J. Ethnopharmacol. 2009, 122, 210.

4. Seghiri, R.; Boumaza, O.; Mekkiou, R.; Benayache, S.; Mosset, P.; Quintana, J.; Estévez, F.; León, F.; Bermejo, J.; Benayache, F.; Phytochem. Lett. 2009, 2, 114.

5. Buruk, K.; Sokmen, A.; Aydin, F.; Erturk, M.; Fitoterapia 2006, 77, 388.

6. Chicca, A.; Tebano, M.; Adinolfi, B.; Ertugrul, K.; Flamini, G.; Nieri, P.; Eur. J. Med. Chem. 2011, 46, 3066.

7. Flamini, G.; Antognoli, E.; Morelli, I.; Phytochemistry 2001, $57,559$.

8. Akram Ghantous, A.; Gali-Muhtasib, H.; Vuorela, H.; Saliba, N. A.; Darwiche, N.; Drug Discovery Today 2010, 15, 668.

9. Bentamene, A.; Benayache, S.; Creche, J.; Petit, G.; BermejoBarrera, J.; León, F.; Benayache, F.; Biochem. Syst. Ecol. 2005, 33, 1061.

10. Kadi-Hanifi, H.; Sécheresse 2003, 3, 169.

11. Ozenda, P. In Flore et végétation du Sahara; $3^{\text {rd }}$ ed.; Centre National de la Recherche Scientifique: Paris, 2004.

12. González, A. G.; Bermejo, J.; Amaro, J. M.; Massanet, G. M.; Galindo, A.; Cabrera, I.; Can. J. Chem. 1978, 56, 491.

13. Ha, T. J.; Yang, M. S.; Pak, Y.; Lee, J. R.; Lee, K. D.; Kim, H. M.; Park, K. H.; Heterocycles 2002, 57, 151.

14. García, B.; Skaltsa, H.; Navarro, F. I.; Pedro, J. R.; Lazari, D.; Phytochemistry 1996, 41, 1113.

15. González, A.G.; Bermejo, J.; Toledo, F.; Daza, L. R.; Phytochemistry 1981, 20, 1895. 
16. Choi, S. Z.; Choi, S. U.; Lee, K. R.; Arch. Pharm. Res. 2005 , $28,1142$.

17. Kim, I.; Chin, Y. W.; Lim, S. W.; Kim, Y. C.; Kim, J.; Arch. Pharm. Res. 2004, 27, 600.

18. Youssef, D.; Frahm, A. W.; Planta Med. 1995, 61, 570.

19. Torres, F.; Quintana, J.; Estévez, F.; Mol. Carcinog. 2010, 49, 464.

20. Negrín, G.; Eiroa, J. L.; Morales, M.; Triana, J.; Quintana, J.; Estévez, F.; Mol. Carcinog. 2010, 49, 488.

21. Karamenderes, C.; Bedir, E.; Pawar, R.; Baykan, S.; Khan, I. A.; Phytochemistry 2007, 68, 609.

22. Cardona, M. L.; García, B.; Pedro, J. R.; Sinisterra, J. F.; Phytochemistry 1989, 28, 1264.

23. Rodriguez, E.; Towers, G. H. N.; Mitchell, J. C.; Phytochemistry 1976, 15, 1573; Scotti, M. T.; Fernandez, M. B.; Ferreira, M. J. P.; Emerenciano, V. P.; Bioorg. Med. Chem. 2007, 15, 2927.
24. Kupchan, S. M.; Fessler, D. C.; Eakin, M. A.; Giacobbe, T. J.; Science 1970, 168, 376.

25. Heilmann, J.; Wasescha, M. R.; Schmidt, T. J.; Bioorg. Med. Chem. 2001, 9, 2189.

26. Garcia-Pineres, A. J.; Lindenmeyer, M. T.; Merfort, I.; Life Sci. 2004, 75, 841.

27. Zhang, S.; Wong, Y. K.; Ong, C. N.; Shen, H. M.; Curr. Med. Chem. Anti Canc. Agents 2005, 5, 239; Cho, J. Y.; Kim, A. R.; Jung, J. H.; Chun, T.; Rhee, M. H.; Yoo, E. S.; Eur. J. Pharmacol. 2004, 492, 85 .

Submitted: November 15, 2011

Published online: April 19, 2012 